\title{
Kritik af Dieter Läpples statsformsbestemmelse
}

\author{
Peter Bundesen, Finn Dam Rasmussen \\ og Henning Jørgensen
}

I denne artikel bringes en kritik af Dieter Läpple's forsøg på grundlæggende at bestemme, hvad den borgerlige stat overhovedet er. Kritikken retter sig mod de forskellige statsudledningsfors $\phi g$, som Läpple fremsætter i den første del af sin bog: Staten og de almene produktionsbetingelser.

I forlængelse af denne kritik skitseres dernæst, hvorfor og hvordan statens almene form ikke kan udledes begrebslogisk, men må indføres i analysen som en historisk given bestemmelse.

I den aktuelle marxistiske diskussion om den kapitalistiske stat og dens funktioner søger Dieter Läpple i sin bog »Staten og de almene produktionsbetingelser « ${ }^{1}$ at præcisere nogle af de bestemmelser, der må ligge til grund for en konkret-historisk undersøgelse - en såkaldt realanalyse - af en given stat i en given periode. Läpples bog falder i to dele, een hvor han grundliggende søger at bestemme, hvad en kapitalistisk stat overhovedet er - det han kalder en formbestemmelse af staten - og een, hvor han nærmere unders $\varnothing$ ger visse af den kapitalistisk stats mulige funktioner, nemlig frembringelsen af de almene produktionsbetingelser. Resultaterne af vore overvejelser omkring Läpples behandling af de almene produktionsbetingelser falder i det store og hele sammen med Marc Festers syns-

1. D. Läpple: Staten og de almene produktionsbetingelser, Kurasje, København, 1973. 
punkter i »Infrastruktur und Kapitalverwertung $«,{ }^{2}$ hvorfor vi angående denne problematik vil nøjes med at henvise til Festers artikel. Hvad vi tager op her er således kun første del af Läpples bog, »Om forholdet mellem økonomi og politik i det borgerlige samfund «.

I bestræbelserne på en oparbejdelse af de begrebsmæssige forudsætninger for statsanalyser har kategoriale statsudledningsfors $\emptyset \mathrm{g}$ indtaget en central plads inden for de senere år, begrundet i bestemmelsen af staten ud fra de polit- $\varnothing$ konomiske kategorier og deres indbyrdes sammenhæng. Omend de forskellige statsudledningsfors $\emptyset \mathrm{g}$ har bevæget sig ad forskellige baner (udgangspunkterne veksler primært mellem »overflade $\ll^{3}$ og »dybde «-

2. M. Fester: »»Infrastruktur« und Kapitalverwertung «, pp. 55-73 i ARCH+, 6. Jg., H. 23, 1974.

3. Vi skal ikke her give nogen indgående behandling af disse »overflade-afledninger « (Marxistische Gruppe/Theoriefraktion: Zur Oberfläche des Kapitals, i CIRKULAR no. 3, erweiterte neuaufl. aug. 1973, og von Flatow/F. Huisken: »Zum Problem der Ableitung des bürgerlichen Staates«, i Probleme des Klassenkampf nr. 7, 1973, oversat i Kursaje nr. 9-10), men blot indskrænke os til principielt at afvise disse fors $\emptyset \mathrm{g}$ som grundlag for en materialistisk statsbestemmelse.

Disse teorier søger at aflede staten ud fra et »ordspil« mellem særlige og almene interesser. Man påstår, at de tre slags revenukildebesiddere, der fremtræder på overfladen, forfølgelse af deres respektive særlige interesser ikke samtidig er i stand til at forfølge de fælles almene interesser. Denne mangel skulle så nødvendiggøre staten, som uafhængig af de tre særinteressegrupper varetager de almene interesser. Men at »forfølgelsen af de særlige interesser udelukker realiseringen af almene interesser, er kun et definitionsspørgsmål. Marx' fremstilling af konkurrencen går netop ud på, at realiseringen af de almene interesser er det ubevidste og utilsigtede resultat af de enkelte privatejerhandlinger.« (B. Blanke/U. Jürgens/H. Kastendiek: »Zur neueren marxistischen Diskussion über die analyse von Form und Funktion des bürgerlichen Staates«, i Probleme des Klassen kampfs, nr. 14/15, 1974, p. 84).

En sådan afledning af staten ud fra en angivelig modsætning mellem forfølgelsen af særlige og almene interesser kan altså ikke begrundes kapitallogisk. Derfor bliver interesserne hos Flatow/ Huisken heller ikke bestemt polit- $\varnothing$ konomisk: »... så forudsætter den første (kategorien: interesse) nødvendigvis skelnen mellem karaktermaske og subjekt, fordi interesser kun i såfald kan ytres, når der består en begrebslig forskel mellem objektiv bestemmelse af ting (penge, vare, kapital) og dens »vogter«, bærer, besidder ..., (i Kurasje nr. 9, p. 142), og endvidere: »Som subjekter, der må føle sig frie for så vidt som de kan råde over deres private ejendom, har de interesser, der udelukkende angår optimal udnyttelse af egen ejendom med henblik på højere revenuudvinding.« (i Kurasje nr. 10, p. 9).

Når staten ikke bestemmes ud fra de kapitallogiske former, men ud fra løst svævende interessebegreber, må man sige, at bestemmelsen falder udenfor rammerne af en materialistisk funderet statsteori. 
bestemmelser ${ }^{4}$ ), har de dog en fælles baggrund i den »kapitallogiske, rekonstruktive « Marx-forståelses sondringer mellem forskellige kapitalanalyseniveauer.

I »Kapitalen « intenderer Marx at udvikle den kapitalistiske produktionsmådes indre lovmæssigheder og sammenhænge, men denne udvikling kunne ikke ske via en empirisk generaliseringsproces, eftersom Marx fandt det utilstrækkeligt for at få begreb om de indre strukturer blot at opsamle og kategorisere de empiriske fremtrædelsesformer. Marx søgte i stedet at udvikle kategorierne af hinanden i den »logisk-dialektiske « fremstilling, startende med de mest abstrakte bestemmelser og bevægende sig skridt for skridt over forskellige konkretiseringsetaper mod de konkrete fremtrædelsesformer på overfladen. I systemet af kritikken af den politiske $\varnothing$ konomi er der derfor indeholdt en rekonstruktion (i tankens medium) af den logik, kapitallogikken, som ligger i og strukturerer den kapitalistiske virkelighed (hvilken specifik form kapitalernes sammenstød end må antage), og logisk metodisk går Marx frem på den måde, at han søger at fremstille alle forhold, så vidt de modsvarer deres begreb, dvs. der ses bort fra alle modifikationer, der ikke selv lader sig udlede af kapitalens almene begreb.

Dette første kapitalanalyseniveau går over to afledningsetaper, der sammenfattes som »kapital i almenhed « (denne almene bestemmelse af den kapitalistiske produktionsmådes lovmæssigheder) og »kapital i sin realitet i almenhed « (fremstillingen af den kapitalistiske produktionsmåde på et alment niveau, hvilket vil sige påvisning af værdilovens »rene« gennemslagsformer under iagttagelse af kapitalens eksistens ved »de mange kapitaler «). Den almene fremstilling i egentlig forstand ender med bestemmelsen af fremtrædelsesformerne på kapitalens overflade. Her er fremstillingen så vidt udviklet, som det er muligt under forudsætningen, at »de virkelige forhold svarer til deres begreb.«

Her viser nødvendigheden sig af det næste kapitalanalyseniveau, nemlig analysen af konkrete gennemslagsformer,${ }^{5}$ hvor konkret dog ikke må forstås som konkret-realhistorisk, thi nogen »realanalyse« er der ikke tale om på dette niveau. »Konkrete gennemslagsformer« anvendes her i en meget bred betydning, idet dette »niveau « skal udgøres af de mulige teori-empiri-formidlinger, som lader sig oparbejde fra den almene undersøgelse, i bestræbelserne på at gøre den almene teoris »rene« bestemmelser adækvate (empiri-optagende) overfor de konkrete fremtrædelsesformer.

I den almene fremstilling (udledningen af kapitalens almene begreb) bestemmes individerne udelukkende som karaktermasker: kapitalisten som personificeret kapital, som udbytter af levende arbejde, og arbejderen som den blotte

4. Som typiske repræsentanter herfor kan nævnes Projekt Klassenanalyse (deres seneste position foretrædes i Oberfläche und Staat, USA, Berlin, 1974) og D. Läpple, som tages op i det følgende.

5. Margaret Wirth i »Zur Kritik der Theorie des staatsmonopolistischen Kapitalismus, (pp. 17-44) i Probleme des Klassenkampfs, nr. 8/9, nr. 3, 1973, p. 19f. 
personifikation af det levende arbejde og hvor disse fremtræder fordrejet som revenukildebesiddere på kapitalens overflade: arbejderen som besidder af revenukilden arbejde, kapitalisten som besidder af revenukilden kapital og jordejeren som besidder af revenukilden jord. Karaktermaskebestemmelserne reflekterer den af de $\varnothing$ konomiske forhold givne, objektive adfærdstvang, dvs. menneskelige handlinger betragtes som ubestemt af enhver form for bevidsthedsakt, der konkret gør handlingerne ikke-konforme med den $\varnothing$ konomisk bestemte karaktermaskeageren. Først når undersøgelsen har bevæget sig ud over den almene fremstilling forudsættes der ikke fuld konform karaktermaskeageren hos individerne: de konkrete lønarbejdere, kapitalister og jordejere. Som sådanne kan individerne agere imod deres $\varnothing$ konomiske bestemmelser.

Følgende principielle kapitalanalyseniveauer må fastholdes:

I. Alment niveau, der indbefatter

a. kapital i almenhed

b. kapital i sin realitet i almenhed.

II. Konkrete gennemslagsformer.

III. Fremtrcedelsesmåde, (kapitalen i sin realitet), dvs. agenternes faktiske aktioner som konkrete individer, niveauet for realanalyse. ${ }^{6}$

Begrundelsen for afgrænsningerne mellem niveauerne må selvfølgelig hentes i indholdet, men da dette kræver en selvstændig undersøgelse, har vi her nøjedes med nogle antydninger (jvf. diskussionen hos W. Schwarz ${ }^{7}$ ), fordi en korrekt statsbestemmelse forudsætter en nøje overholdelse af niveaudistinktionerne.

Denne korte præcisering af analysegangen i kritikken af den politiske $\varnothing$ konomi har været nødvendig for at fundere en kritik af Läpples statsudledning.

I næste afsnit vil vi tage Läpples statsformsbestemmelse op og fors øge at påvise inkonsistenserne $\mathrm{i}$ denne, for i sidste afsnit i positiv form ansatsvis at påpege, hvorledes staten må bestemmes.

6. Selve betegnelserne »gennemslagsformer« og »fremtrædelsesmåde « har vi hentet fra Wirth, men indholdsmæssigt er der betydelig forskel mellem hendes bestemmelser og vore. For det første: Medens Wirth fejlagtigt først reflekterer monopolet på niveauet »gennemslagsformer«, så omfatter det almene niveau også dannelsen af gennemsnitsprofitraten, hvorfor monopolet, bestemt som: hindringer i profitratens udligning, også må reflekteres på dette niveau. Altså medens det almene niveau afsluttes på kapitalens overflade, så er det ikke klart, hvor det afsluttes hos Wirth.

For det andet: Wirth knytter sin overgang fra andet til tredie niveau sammen med en ophævelse af karaktermaskebestemmelserne, således at individerne på det tredie niveau bestemmes som »frie subjekter« (p. 20). Heroverfor mener vi, at karaktermaskebestemmelserne ikke kan reserveres til de to første (eller det første) af de tre undersøgelsesniveauer, idet individerne også konkret fremstår i deres karaktermaskebestemmelser. Blot kan deres faktiske adfærd ikke reduceres til den $\varnothing$ konomisk givne karaktermaskeadfærd.

7. W. Schwarz: Das »Kapital im allgemeinen« und die »konkurrenz« im ökonomischen Werk von Karl Marx. Zu Rosdolskys Fehlinterpretation der Gliederung des »Kapital«; i: Gesellschaft nr. 1, 1974, pp. 222-247. 
Läpple skriver indledningsvis, at hans undersøgelse skal forstås som et bidrag til analysen af forholdet mellem $\varnothing$ konomi og politik i de højt udviklede kapitalistiske lande. Men da den for det borgerlige samfund basale bestemmelse af forholdet mellem $\varnothing$ konomisk og politisk struktur, som ligger til grund for det faktiske forhold mellem disse, ikke er tilfredsstilende udarbejdet, vil Läpple i bogens første kapitel foretage en sådan bestemmelse. Läpples undersøgelse bliver således et led i de verserende bestræbelser på at udlede staten i det kapitalistiske samfund ud fra kritikken af den politiske økonomi.

Läpples statsudledning starter indholdsmæssigt ud fra byttet i den simple cirkulation, idet det først er her produktionens - gennem den samfundsmæssige arbejdsdeling - samfundsmæssige sammenhæng bliver sat. Men hans udledningsfors $\varnothing \mathrm{g}$ løber omgående ind i problemer. Og hvor usammenhængende og modsætningsfuld, Läpples statsudledningsforsøg er, kan anskueliggøres ud fra den centrale argumentation, pp. 30-31, der først skal citeres i sin helhed:

»Varebesiddernes frihed og lighed er altså et produkt af den udviklede bytteværdiproces. For at disse varebesiddere imidlertid virkelig skal forholde sig til hinanden som frie og lige, er det ikke tilstrækkeligt, at der på den ene side findes en $\varnothing$ konomisk struktur, der kræver og muliggør vareproduktion og vareudveksling, og på den anden side, at ideerne om frihed og lighed er tilstede i varebesiddernes hoveder; der kræves dertil også en real juridisk og politisk struktur, der svarer til den økonomiske, og som sætter varebesiddernes frihed og lighed som bindende kommunikationsformer; en politisk og juridisk struktur, der bevirker, at varebesidderne »Forholder sig til hinanden som personer, hvis vilje er knyttet til tingene (de udvekslede varer - D.L.), således at den ene kun med den andens vilje, altså at hver kun formedelst en for begge fælles viljesakt, kan tilegne sig den fremmede vare, idet han afhænder sin egen. De må gensidigt anerkende hinanden som privatejere.«(Kapitalen, 1.bind 1., p. 186).

Det er nemlig ikke således, at varebesidderne forudsætningsløst anerkender hinanden som privatejere. Omend de enkelte privatproducenter nødvendigvis må optræde som privatejere, er de ikke parate til, uden videre at anerkende privatejendommen som sådan. »Bourgeoisiet forholder sig til sit regimes institutioner som jøden til loven; han omgår den så ofte, det i hvert enkelt tilfælde er muligt, men han vil, at alle andre skal holde den.« (Die deutsche Ideologie, p. 162f) «.

At vi her har at gøre med direkte modstridende udsagn er oplagt:

1. Først er friheden og ligheden produkter af selve bytteprocessen. Således er staten netop ikke nødvendig for at sikre ækvivalentbyttet. Havde Läpple holdt fast ved dette, kunne han have sparet hele sit fors $\emptyset \mathrm{g}$ på at udlede staten fra vareanalysen.

2. I næste sætning får vi at vide, at »ideerne« om frihed og lighed også må være til stede i varebesiddernes bevidsthed.

3. Dernæst postuleres yderligere nødvendighed af en statslig-juridisk instans til sikring af frihed-lighedsforholdene, for at gøre disse til »bindende kommunikationsformer «. 
4. Som belæg for statens »fremanalyserede« nødvendighed på dette sted fremdrages et Marx-citat. Läpple generes imidlertid ikke af, at citatet modsiger det, som tekststykket var hentet frem for at »bevise«, nemlig statens nødvendighed som sikrer af frihed-lighedsforholdene. Marx påpeger netop i citatet, at varebesiddernes "vilje er knyttet til tingene « - altså er friheds-lighedsforholdene produkt af udvekslingsprocessen.

5. Läpple finder det imidlertid påkrævet at argumentere yderligere for statens nødvendighed. Var frihed-lighedsforestillingerne til stede i varebesiddende hoveder, og sikrede staten frihed-lighed som bindende kommunikationsformer, så viser det sig nu på trods heraf, at privatejerne samtidigt alligevel ikke vil anerkende privatejendommen. Hvorfor nu ikke det? Nej, for man (og »man« er pludselig bourgeoisiet og ikke vore varebesiddere!) forholder sig til samfundets institutioner som jøden til loven: man søger at omgå loven konsekvent. Her bliver statens eksistens begrundet i nødvendigheden af at sikre privatejendommen imod overgreb, men dette sker som påpeget ikke ud fra $»$ vareanalysen $\ll$.

Man vil lede forgæves efter en retfærdiggørelse af disse åbenbare modsigelser hos Läpple. På baggrund af ovenstående kan det heller ikke undre, at Läpple i sin foreløbige konklusion serverer endnu en ny »statsudledning " (som ganske vist tidligere er antydet, men som slet ikke er blevet udviklet), der denne gang sker ud fra arbejdets særlige karakter i det »borgerlige« samfund:

»Den modsigelse, der i det borgerlige samfund er indeholdt $\mathrm{i}$ arbejdets særlige samfundsmæssige form, fremkalder altså den borgerlige stats formspecificitet.« (p. 32)

Efter »statsudledningen« fra den simple varecirkulation bevæger Läpples fremstilling sig frem til det punkt, hvor den simple varecirkulation underordnes den kapitalistiske produktionsproces, dvs. der hvor bestemmelserne fra den simple cirkulation, der syntes at hvile på udveksling af eget arbejde, slår om i loven for den kapitalistiske tilegnelse, en lov, der ifølge Läpple må sikres af statens magtmonopol. Med selvstændiggørelsen af produktion og cirkulation finder der - stadig ifølge Läpple - en fordobling af herredømmets form sted: dels udøves der et direkte $\varnothing$ konomisk herredømme i produktionssfæren (gennem enkeltkapitalisterne), og dels formidler cirkulationssfæren bourgeoisiets klasseherredømme, som en politisk form. Nu er det altså lykkedes for Läpple at få anbragt staten som politisk form i den økonomisk bestemte cirkulationssfære. Ved denne »overgang « til kapitalistisk tilegnelse bliver statens nødvendighed nu også begrundet i nødvendigheden af med magt at sikre kapitalistisk tilegnelse. - Hermed mener Läpple at det specifikke forhold mellem $\varnothing$ konomi og politik i det borgerlige samfund skulle være bestemt i sin grundstruktur (pp. 34-40).

En yderligere vanskelighed ved Läpples analyse er hans grundige sammenblanding af og spring imellem forskellige konkretiseringsområder. Man kan blot henvise til fejltagelsen i denne henseende, hans allerede nævnte sætten de indledende bestemmelser fra den simple cirkulation sammen med de subjektive 
bevidsthedsprocesser hos varebesidderne. Läpple lader ideerne om frihed og lighed være til stede »i varebesiddernes hoveder « (p.30), samtidig med at disse betragtes som uvillige til og konsekvent nægtende at anerkende hinanden som besiddere af privatejendomme. Herved når Läpple frem til nødvendigheden af en til den $\varnothing$ konomiske struktur svarende juridisk-politisk struktur, som »sætter varebesiddernes frihed og lighed som bindende kommunikationsformer.« (p.30). At udledningen er svagt funderet synes Läpple selv klar over, og han søger at udbygge sin begrundelse ved at supplere med behov for en sikring af den gensidige anerkendelse af privatejendommen. - Betragtningen af bytteprocessen og dens forudsætninger sker inden for den simple varecirkulation, hvor det ifølge Läpple er således, at »Omend de enkelte privatproducenter nødvendigvis må optræde som privatejere, er de ikke parate til, uden videre at anerkende privatejendommen som sådan« (p.31). Som nærmere belæg for dette fremdrager Läpple som nævnt følgende citat:

»Bourgeoisiet forholder sig til sit regimes institutioner som jøden til loven; han omgår den så ofte, det i hvert enkelt tilfælde er muligt, men han vil, at alle andre skal holde den.« (citeres efter Läpple, p. 31).

Ikke nok med at argumentationen nu udvikles fra nogle opfattede subjektive forhold (funderet $\mathrm{i}$ et citat fra en anden sammenhæng), men pludselig har vi også fået introduceret bourgeoisiklassen, der i systemet af kritikken af den politiske $\varnothing$ konomi først lader sig identificere og analysere efter udviklingen af kapitalbegrebet. Den simple varecirkulations bestemmelser er netop første skridt mod blotlæggelsen af det kapitalistiske samfunds klassekarakter. Springet i den logiske fremstilling blokerer for en stringent statsformsudledning som følger Läpples egne intentioner, idet han for at begrunde staten påberåber sig faktorer - bourgeoisiet, »borgerlige individer« (p.32) -, der ikke er bestemt på det behandlede sted i fremstillingen.

Projekt Klassenanalyse (PKA) går i en af de foreliggende kritiske kommenteringer af Läpples bog nærmere ind på Läpples opfattelse af, hvad der skal forstås ved varernes lighedssætning i bytteprocessen. ${ }^{8}$ PKA har ret $\mathrm{i}$, at Läpple ikke ser varernes formbestemmelse i bytte-processen som et specifikt samfundsmæssigt forhold, men lader selve bytteakten konstituere et sådant: »Ved at sætte produkter lige i byttet får vi deres værdi, som blot en substans af forskelløst menneskeligt arbejde, de træder frem i byttet som bytteværdi. »(Läpple, p. 28). Men forudsætningen for at en sætten arbejdsprodukter lig hinanden i bytteprocessen overhovedet er mulig netop den, at disse har en fælles sammenligningsdimension, og denne findes i varernes værdiegenskab, kvaliteten at være resultat af abstrakt menneskeligt arbejde. I den konkrete bytteakt får den samfundsmæssige vurdering af det i varen nedlagte arbejde sit kvantitative udtryk i varens bytteværdi, men denne vurdering eller sammenligningsproces kan netop kun gennemføres, fordi de foreliggende pro-

8. Se PKA: Oberfläche und Staat, op. citat, pp. 167-195. 
dukter repræsenterer en værdiskabelse, et samfundsmæssigt forhold. - Men PKA går videre og hævder, at udvekslingsprocessen kun kan etableres, når varebesidderne i deres karaktermaskeegenskab over for hinanden udtrykker de фkonomiske forholds grundvilkår: de må gensidigt anerkende hinanden som privatbesiddere, og bytteakten bekræfter blot, at denne forudsætning, dette »viljesforhold «, som udtryk for den $\emptyset$ konomiske struktur, er tilstede. Läpple lader imidlertid byttehandlingen - hos ham lig værdisætningen - konstituere den kapitalistiske $\varnothing$ konomi, og den gensidige anerkendelse fra vareejernes side interpreteres som hovedforudsætningen for byttet. Läpple griber her til at forudsætte ligheds- og frihedsideerne værende til stede i varebesiddernes bevidsthed, men samtidig tolke disse som nægtende at anerkende privatejendommen. Läpple sætter ikke frihed og lighed i sammenhæng med den reale basis, den $\varnothing$ konomiske struktur, men henfører dem til »de borgerlige individers « feticherede bevidsthed.

Bytteprocessen kan ikke bestemmes ud fra individernes subjektive orientering; de økonomiske forhold må netop i personernes ageren på markedet få deres nødvendige refleks, idet varebesidderne som mere eller mindre atomare agenter på markedet tvinges til samfundsmæssigt set at forholde sig lige overfor hinanden. Läpple henlægger imidlertid her ligheds- og frihedssikringens varetagelse til den statslige juridisk-politiske instans. Kun gennem eksistensen af en (statslig) institution med suveræn magtudøvelsesrettighed kan ækvivalentbyttet sikres, idet det gøres lovfæstet i den »offentlige « magts retssystem, som »sætter frihed og lighed som bindende kommunikationsform «. Sammenflettet med denne bestemmelse af staten var Läpples bestemmelse af statens eksistens som garant for privatejendommen, men denne eksistens afledes ikke af de økonomiske forhold, som det var intenderet i begyndelsen af bogen, nemlig fors $\emptyset$ get på at »udvikle en grundstruktur for den almene bestemmelse af staten ud fra det borgerlige samfunds økonomiske struktur.«(p.8) I denne henseende kan man sige med PKA: »Staten bliver ... fra et afledet moment af den samfundsmæssige sammenhæng til konstituens for denne sammenhæng.«. (PKA, p. 186). Hvad der skulle afledes, bliver til forudsætning for selvsamme afledningsgrundlag.

I. h. t. Läpples egen metodeforståelse kan genstand og metode ikke uden videre betragtes isoleret, dvs. metode kan ikke anskues som et invariant, generelt anvendbart redskab, men en henvisning til metoden må være genstandsspecifik. Ikke desto mindre begrunder Läpple netop sin »videnskabelighed « i metodisk henseende ved at postulere en overensstemmelse mellem hans og Marx's fremgangsmåde; herved udraderer han jo objektet for sin analyse: staten som en udenfor kapitalens kredsløb stående institution, en institution, der er fixpunkt for politiske forhold. (Man kan også gøre opmærksom på, at Läpple tilsyneladende arbejder med en lighedssætning mellem stat og politik). Staten beror i.h.t. Läpple på økonomien, og delingen mellem $\emptyset$ konomi og politik skulle derfor være at forklare ud fra kapitalens begreb. Udgangspunktet for Läpples analyse af staten, der noget forvirrende 
skiftevis sættes til at skulle være »arbejdets dobbeltkarakter «, »det borgerlige samfunds basis «, »individernes materielle liv« etc., og som viste sig at være vareanalysen, bliver også indeholdt i statens karakteristik. - Resultatet af analysen synes at ligge færdig for ham, inden argumentationen udvikles, og argumenterne hentes fra forskellige steder i Marx'. produktion - oftest i form af analogislutninger eller »metodiske præciseringer «. »Afledningen « afslører, at Läpple ikke kan identificere noget objekt for den videnskabelige analyse, men må nøjes med at lade klassiker-citater saltet op med egne kommenteringer give staten et indhold, der synes at være af overvejende $\varnothing$ konomisk karakter.

På baggrund heraf er det ikke overraskende, at Läpple ikke kan løse de problemer, han derefter tager op m.h.t. selvstændiggørelsen af produktions- og cirkulationsprocesserne og den dertil modsvarende fordobling af herredømmets udøvelse: Läpple kan simpelthen ikke reflektere formidlingen herimellem, hvilket er forståeligt, når man betænker, at han ikke kunne udsondre nogen ikke- $\varnothing$ konomisk sfære, men placerede staten i cirkulationssfæren. (Läpple bruger også upræcist cirkulation og cirkulationssfære synonymt).

Sammenfattende om udledningsfors $\varnothing$ get kan siges, at staten både gives et tilsyneladende $\varnothing$ konomisk indhold (»placeringen « af staten i cirkulationssfæren) og bliver til eksistensgrundlag for de $\varnothing$ konomiske forhold i stedet for som intenderet af blive afledt af disse. Samtidig springer Läpple uden videre mellem forskellige konkretiseringsetaper uden at betragte den nærmere gang i og forskningslogiske implikationer af en sådan fremgangsmåde, der intenderer at være i overensstemmelse med marxske teoretisk-metodiske principper.

Endelig kan der være grund til at anholde den udbredte praksis, som man finder både hos Läpple og visse andre statsudledningsfors $\varnothing \mathrm{g}$, nemlig fremdragelsen af det ene marxske tekststykke efter det andet som belæg for sine udsagns rigtighed. Det er udtryk for en angribelig dogmatisme, såfremt man altid vil anholde udsagns rigtighed med henvisning til, at Marx på et eller andet sted i sin produktion sagde noget andet (eller sagde noget, der kunne tolkes i en anden retning - hvilket ikke turde være forbundet med de store åndelige anstrengelser); en sådan »bevisførelse« er kun lig formuleringsforskelle og intet andet. Det vil derfor være fremmende for den videre statsdiskussion, hvis vi kommer bort fra, at man blot ved at påpege, at Marx skrev noget andet, kan afkvalificere det ene eller det andet bidrag. ${ }^{9}$

9. For en nærmere kritik af »citatrytteriet « se Theoretisches Organ der Roten Zellen/AK München: Resultate der Arbeitskonferenz, 1. Jg., Nr. 1, September 1974 (pp. 120-170: »Warum scheitern Marxisten an der Erklärung des bürgerlichen Staates?«). 


\section{III}

Läpple kan altså ikke, som det var hans intention, udlede staten - som den instans, der skal sikre frihed og lighed mellem privatejerne i bytterelationen - af den $\varnothing$ konomiske sammenhæng, men han må derimod gøre statens eksistens til forudsætning for denne. ${ }^{10}$

Det er rigtigt, som Projekt Klassenanalyse påpeger, at frihed og lighed i byttet ikke sikres af staten, ${ }^{11}$ samt at ligheden sættes gennem byttet ved den af Projekt Klassenanalyse betegnede »Ins-Mass-Setzen « af de forskellige kvanta samfundsmæssigt arbejde (PKA p. 184). Men selve forudsatningen for byttet, de udvekslendes gensidige anerkendelse som privatejere, sikres ikke i eller af byttet, idet denne anerkendelse jo netop udgør konstituens for dette. Derfor kan bestemmelserne for sikringen af privatejendommen heller ikke udledes af de $\varnothing$ konomiske relationer, men er en nødvendig historisk forudsætning for bytteforholdets gennemslag og eksistens som dominerende samfundsrelation.

Vi vil her argumentere for, at statsbestemmelsen må ske ud fra nødvendigheden af en bytteforholdet ekstern instans til sikring af privatejendommen, og at denne bestemmelse ikke er i strid med de antydninger til statsformsbestemmelse, som Marx har givet i kritikken af den politiske økonomi. Ganske vist analogiserer Marx i Grundrisse (p.83) afledningen af pengeformen med statsformens bestemmelse, men den antydning giver ingen holdbar begrundelse for at antage, at den reale fordobling af varen i vare og penge kan duplikeres i en tilsvarende fordobling af samfundet i samfund og stat.

Vi vil altså ikke forsøge, at udlede statsformen begrebslogisk, idet vi mener, at staten - som instansen, der skal sikre privatejendommen -

10. PKA bebrejder Läpple, at han ikke kan aflede staten af de samfundsmæssige sammenhænge, men må gøre den til konstituens for disse. (Oberfläche und Staat, op. cit., p. 186) Vi er enige med PKA i, at Läpple punktuelt bestemmer staten som forudsætning (f.x. på p. 32), men vi er uenige med PKA, idet vi netop mener, at dette er den korrekte måde at bestemme staten på.

11. En sådan forestilling om at staten skulle kunne sikre frihed og lighed ved varebyttet er urimelig. For hvis staten skulle garantere ligheden i byttet skulle den sikre, at lige store mængder abstrakt samfundsmæssigt arbejde blev udvekslet, og dette ville forudsætte en direkte statslig overvågning af produktionsprocesserne. I så fald ville der ikke være tale om uafhængige privatproduktioner, arbejdet ville være umiddelbart samfundsmæssigt, og markedets »Ins-Mass-Setzen« af de forskellige mængder forbrugt arbejde ville være ophørt. Da friheden i forbindelse med det simple varebytte består i at kunne vælge imellem forskellige brugsværdier, må den (friheden) forudsætte et eller andet præferencehieraki, der ikke kan bestemmes hos varebytterne som karaktermasker, men som subjekter, hvor de også er udstyret med viljer og bevidsthed, der gennembryder de kapitallogiske bestemmelser. Derfor angår frihedens forhold ikke direkte byttets $\varnothing$ konomiske formbestemmelser. Af dette skulle det også fremgå, at Läpples ureflekterede sammenstilling af frihed og lighed er metodisk utilladelig, idet friheden bestemmes på brugsværdisiden, medens ligheden bestemmes på værdisiden. 
skal bestemmes som en nødvendig forudsætning for kapitalistisk vareproduktion. ${ }^{12}$

\section{I andet kapitel af »Kapitalens « 1. bind skriver Marx:}

Varerne kan ikke selv på til markedet og ikke udveksle sig selv. Vi må altså se os om efter deres ejermænd, varebesidderne. Varerne er ting og derfor modstandsløse overfor mennesket. Er de ikke villige kan han bruge magt, med andre ord tage dem. For at sætte disse ting i forhold til hinanden som varer, skal varebesidderne forholde sig til hinanden som personer hvis vilje har til huse i de pågældende ting, således kun den ene med den andens samtykke, begge altså kun ved en fælles viljesakt, tilegner sig den andens vare samtidig med at afhænde sin egen. De må derfor gensidigt anerkende hinanden som privatejere. (1. bog 1., p. 186, vor understregning).

Forudsætningen for at byttet overhovedet kan finde sted i samfundsmæssig målestok er altså en gensidig anerkendelse af alle andres privatejendom. Staten formbestemmes ud fra den simple cirkulation som en udenfor byttet stående instans, der gennem et retssystem og den dertil knyttede tvangssikring garanterer forudsætningen for bytteprocessen: den gensidige anerkendelse af privatejendommen, hvis formaliserede udtryk er privatejendomsretten. I denne sammenhæng bliver analogien mellem bestemmelsen af penge og stat forsvarlig, idet analogt med varens fordobling i vare og penge kløves samfundet $i$ to forskellige »systemer « af sociale relationer: samfund og stat.

Statsformen er altså først bestemt ud fra den simple cirkulation, men bestemmelsen udvikles ved fremstillingens overgang til kapitalforholdet, hvor vareformen også omfatter arbejderens arbejdskraft. Heraf følger for arbejderen en dobbelt adskillelse: 1) adskillelsen fra produktionsmidler, hvilket gør ham til ikke-ejer, 2) adskillelsen af hans arbejdsevne fra hans person - arbejdsevnen må i form af varen arbejdskraft stå fremmed overfor dens bærer, arbejderen, og kun have brugsværdi for ham for så vidt, den har bytteværdi, dvs. brugsværdi

12. Vel vidende at begreberne: udledning, afledning og bestemmelser almindeligvis bruges i flæng, $\emptyset$ nsker vi dog at opretholde en begrebslig distinktion mellem udledning afledning) og bestemmelse. Statsudledningstankegangen må forstås som et forsøg på at fastlægge staten som et immanent resultat af den kapitalistiske produktionsmådes indre lovmæssigheder. Statsbestemmelse reserverer vi derimod til fastlæggelse af staten som en nødvendig (historisk) forudsætning for den kapitalistiske produktionsmåde.

Den begrebslige forskel i fastlæggelse af »kapitalistisk samfund « og »kapitalistisk stat « har Marx antydet i sin kritik af Gotha-programmet: »Det »nuværende samfund « er det kapitalistiske samfund, som eksisterer i alle kulturlande, mere eller mindre frit for middelalderlig tilsætning, mere eller mindre modificeret ved hvert lands særlige historiske udvikling, mere eller mindre udviklet. Den »nuværende stat« veksler derimod med landegrænserne. Den er en anden i det preussisk-tyske rige end i Sveits, en anden i England end i De forenede stater. Den »nuværende stat « er altså en fiktion. « Hvor udviklingen af kapitalbegrebet sker gennem en væsenslogik, kan staten begrebsligt ikke fastlægges tilsvarende, omend staten, som Marx skriver, »står på det borgerlige samfunds grund, og derfor kan siges at have visse væsentlige karaktertræk til fælles.« (Marx: Randbemærkninger til det tyske arbejderpartis program, (pp. 11-42) i K. Marx og F. Engels: Udvalgte Skrifter, bind II, Tiden, København 1952, p. 25). 
for andre. Først i og med at arbejdskraften er bragt på vareform, er det muligt for arbejderen at etablere en ejensomsrelation til (en del af) sig selv. Hermed er han »privatejer«. I relationen mellem arbejder og kapitalist må arbejderens privatejendom af arbejdskraften forudsættes inden fremstillingen af udviklede kapitalistiske forhold, for hvis arbejderen ikke selv udenfor og ved kontraktforholdets indgåelse »ejer « sin arbejdskraft, men er underkastet en enkeltkapitalists råderet, så opløses kapitalforholdet. Kapitalistklassens privatejendom til produktionsmidlerne må ligeledes forudsættes. Marx bestemmer kapital dels som »kapital som ejendom « og dels som »kapital som funktion « (Kapitalen, 3. bind 2., p. 429 og 3.bind 3., pp. 801-802). I fremstillingen behandler Marx »kapital som funktion « (valoriseringsegenskaben), idet bestemmelsen af »kapital som ejendom « (privatejendom) er forudsat. Forudsætningen om at arbejderen ejendomsmæssigt er skilt fra produktionsmidlerne indkluderer også adskillelsen fra produktionsmidlet jord (de ikke-reproducerbare produktionsmidler). Derfor må privatejendommen til disse, som kun er bestemt som »kapital som ejendom«, være forudsat.

Staten er på dette niveau i fremstillingen bestemt som et system af sociale relationer, der står udenfor kapitalforholdet, og som kan tildeles organiseringen af funktioner, der sikrer dette forholds nødvendige forudsætninger. Et system af sociale forhold, der sætter individerne lige i relation til deres bestemmelse som privatejere. Dette er det materielle grundlag for forestillingerne om staten som en over klasserne hævet neutral instans.

Statens bestemmelse som en uden for kapitalforholdet eksisterende instans muliggør, at staten kan intervenere i kapitalforholdet, og historisk har den da også været i stand til at påtage sig at gribe ind i forholdet mellem klasserne. Men da disse forhold ikke på grundlag af kapitalforholdet konstituerer sig som immanent nødvendige men kun som mulige funktioner, kan de ikke bestemmes på dette almene niveau, men bestemmelsen må foretages på et mere konkret niveau. ${ }^{13}$

13. Vi må således afvise den udbredte tendens til at forsøge at lave en almen statsbestemmelse, som i sit »væsen« allerede i kimform indeholder alle statens funktioner. Sådanne bestræbelser hviler på en misforstået analogislutning mellem stats- og kapitalbegrebet. Man bestræber sig altså på at anvende samme metodiske fremgangsmåde ved fastlæggelsen af de to objekter. (Se også: Blanke/Jürgens/Kastendiek, op. cit., pp. 60-69, og pp. 83-89) Denne kritik rammer både Läpple og Flatow/Husiken. Läpple når han vil bestemme staten ud fra modsætningen mellem særlige og almene interesser, hvor staten fastlægges som varertager af »almen-interessen«; og Flatow/Husiken, hvor statens faktiske funktioner blot er fremtrædelser for den borgerlige stats »væsen«, varetagelsen af de »almene interesser«. (Flatow/Huisken, i Kurasje nr. 10, pp. 38-39).

Denne afvisning af en »væsenafledning « af den borgerlige stat indeholder selvfølgelig også en afvisning af ethvert forsøg på at fastlægge staten som »ideel totalkapitalist « (som Läpple gør på p. 41). Opfattelsen af staten som sådan bygger på en sammenblanding af kapitalens og statens begreber. Denne sammenblanding implicerer, at staten bestemmes med et $\varnothing$ konomisk indhold, hvorfor en reflektion af forholdet mellem $\emptyset$ konomi og politik på forhånd er udelukket. Denne økonomiske fastlæggelse af staten må også medføre en 
Når pengene i bestemte funktioner erstattes af pengetegn, er det nødvendigt med en instans uden for byttet, der garanterer disses tvangskurs (Kapitalen, 1.bind 1., pp.235-37). Men derfor kan vi alligevel ikke opfatte statens sikring af tvangskursen som en immanent nødvendig bestemmelse, for som pengetegn svarer de ikke længere til pengenes begreb (1. bind 1., p. 251), hvorfor substitueringen af penge med pengetegn ikke er en immanent nødvendighed, men blot sker af funktionelle grunde, hvor eksistensen af adækvate forhold muliggør det. Ligeledes kan vi i denne almene bestemmelse af staten heller ikke inddrage statens specificering som »nationalstat « (altså eksistensen af flere nationale kapitaler) og de deraf følgende nødvendige og mulige funktioner, for når vi inddrager flere nationale kapitaler, har vi bevæget os ud over de bestemmelser, der kan foretages under behandlingen af de almene kapitalbestemmelser, hvor det forudsættes, at »forholdene svarer til deres begreb«, og de statsfunktioner, der kan bestemmes derefter er således ikke længere immanent udspringende af kapitalbegrebet.

I forbindelsen med fremstillingen i »Kapitalen« vil der kunne nævnes forhold, f.eks. kreditvæsen, hvor statens sikring af privatejendommen er påkrævet, men denne gennemgang vil ikke blive foretaget her, da disse funktioner ikke er konstituerende for statsformsbestemmelsen, men blot angiver konkrete områder, hvor staten må fungere som sikrer af privatejendommen. Denne gennemgang hører ind under en systematisk oparbejdelse af statens mulige funktioner.

Et afgørende problem, som tilsyneladende ikke har været taget op her, er: hvorfor er det nødvendigt med en instans udenfor kapitalforholdet til sikring af privatejendommen? Hvorfor er denne ikke ukrænkelig? Svaret på dette spørgsmål kan ikke udledes af de almene kategorier. Sålænge man i fremstillingen forudsætter, at agenterne optræder som karaktermasker, kan de kun handle i overensstemmelse med bestemmelserne givet af kapitalforholdet, med andre ord implicerer karaktermaskebestemmelsen kapitalforholdets forudsætninger. Agenterne i deres karaktermaskebestemmelse kan således ikke være i besiddelse af intentioner, der ikke er totalt subsumeret rene kapitalbestemmelser. De $\varnothing$ konomiske forhold og individernes adfærd betragtes derfor som kongruente størrelser, hvilket implicerer, at karaktermaskebærerne ikke kan udstyres med en bevidsthed om, at privatejendommen ikke er det naturgivne grundlag for ethvert samfundsmæssigt samkvem. Kun som reale subjekter, hvor agenternes handlinger og bevidsthed gennembryder karaktermaskebestemmelserne, er det muligt for dem at anfægte kapitalforholdets forudsætninger, og det er som sådanne, at individerne danner de reale forudsætninger for den historiske form for klas-

negligering af klassekampens betydning for statens faktiske aktiviteter. For en sådan opfattelse kan klassekampen overfor statens enkelte aktiviteter kun fremtvinge svingninger omkring kapitalens almene (fælles) interesser, for staten er jo på forhånd defineret som varetager af disse interesser. Denne slags statsfastlæggelser nærmer sig således i betænkelig grad det tautologiske. 
seherredømme og udbytning, der reflekteres i kapitalforholdet. Men det gør de ikke godvilligt: »Det tager århundreder, inden den »frie « arbejder, som følge af en udviklet kapitalistisk produktionsmåde, frivilligt går med til, dvs. samfundsmæssigt er tvunget til, at sælge hele sin aktive levetid, ja selve sin arbejdsevne for prisen af sine sædvanlige livsfornødenheder, sin førstefødselsret for en ret linser.« (Kapitalen, 1.bind 2., p. 416 med rettelse). Under udviklet kapitalistisk produktionsmåde gives heller ingen permanent garanti for arbejderens anerkendelse af kapitalismens forudsætninger.

Når vi i nødvendighedsbestemmelsen af staten kun kan bestemme den som: sikrer af privatejendommen i en ud af den samfundsmæssige produktionsform given form, så ville en direkte overgang fra denne bestemmelse til en konkret historisk undersøgelse medføre, at vi var henvist til udelukkende at opsamle de $\varnothing$ vrige bestemmelser fra empirien. Vi er derfor uenige med M. Wirth, når hun skriver, ${ }^{14}$ at de opgaver som staten gennemfører ud over de af hende udledte funktioner (sikring af reproduktionen gennem medierne ret og penge), kun kan bestemmes konkret historisk (Wirth, p. 37). Inden den konkrete historiske undersøgelse må der nødvendigvis foretages mere generelle undersøgelser på niveauet, hvor staten også er bestemt i relation til en nationalkapital - af f.eks. statens forhold til de almene produktionsbetingelser - der fastlægger mere generelle bestemmelser end de realhistoriske; Marx's vejeksempel i Grundrisse viser således hen til et eksempel på sådanne undersøgelser.

14. Wirth, der ligesom os ikke søger at aflede staten af kapitalforholdet, men også mener, at den må forudsættes (p. 31), når frem til, at den må forudsættes som sikrer af reproduktionen, henholdsvis klasserne og produktionsmidlerne (p. 33). Denne bestemmelse synes dog at være for uklar, idet den svarer overens med vor, såfremt den blot udtrykker, at klasserne skal reproduceres i betydningen: opretholdelse af produktionsforholdene, men hvis der med udtrykket »sikring af reproduktionen « også angives noget om, hvilken tilstand klasserne af privatejere skal forefindes i, så tilstræbes der bestemmelser, der er umulige på dette almene niveau, og som derfor kun kan bestemmes på et mere konkret. Derfor vil vi fastholde den præcise bestemmelse »sikrer af privatejendommen « fremfor »sikrer af reproduktionsprocessen «.

\begin{abstract}
Proletarische Front. Gruppe Westdeutscher Kommunisten: Imperialismen $i$ dag. 304 sider. 45 kroner. PF-GWK forsøger at vise, hvordan den nuværende overakkumulationskrise i de imperialistiske centre markerer afslutningen på 3 . fase i arbejdets reelle subsumtion (dvs. underordningens form) under kapitalen. Men krisen i forholdet mellem centre og periferi er derimod karakteriseret ved afslutningen på en imperialistisk fase, hvor det såkaldte "ulige bytte " har været dominerende princip, og hvor det eneste imperialistiske svar i dag er oprettelsen af en række relativt selvstændige, nye akkumulationscenter.
\end{abstract}

\title{
Forlaget MODTRYK
}

Anholtsgade 4, 8000 Århus C.

Postgiro 5216478 . Telefon (06) 127912 